\title{
Adab and Akhlaq in the Islamic Scientific Tradition: Reflection on Curriculum at UNIDA Gontor
}

\author{
Fitra Awalia Rahmawati ${ }^{1}$, Nurul Salis Alamin ${ }^{2}$, Neneng Uswatun Hasanah ${ }^{3}$, Iman Nur \\ Hidayat $^{4}$, Umi Mahmudah ${ }^{5}$ \\ \{fitraawaliarahmawati@unida.gontor.ac.id ${ }^{1}$, nurulsalisalamin@unida.gontor.ac.id² ${ }^{2}$, \\ nenenguswatunhasanah@unida.gontor.ac.id ${ }^{3}$, imannurhidayat@unida.gontor.ac.id $^{4}$, \\ umimhamudah@unida.gontor.ac.id $\left.{ }^{5}\right\}$ \\ University of Darussalam Gontor, Jl. Raya Siman km 6 Siman Ponorogo
}

\begin{abstract}
The Islamization idea was one of the efforts in conducted dialogue with other civilizations and also maintaining the identity and essence of Islam itself. The rise of the Islamic ummah can be started from mastery and deepening of knowledge followed by good Adab and Akhlaq. This Study was concentrated on elucidating Gontor's Curriculum which contained the implementation of Islamization idea. It was a critical study about some aspect of curriculum which is projected the similarity of Islamic worldview such as; the concept of God, knowledge, Adab and Akhlaq. We conclude positive aspects of some Islamization idea in Gontor's curriculum. These aspects which built an Islamic spirit in their scientific activities and other development in line with Gontor's orientation.
\end{abstract}

Keywords: Adab and Akhlaq, Islamization, Curriculum.

\section{Introduction}

The discussion about Islamization can't be separated from knowledge ('ilm), believe (Iman), and character (Akhlak). Depend on Ottoman's fall at 1924; some Muslim scholars had analyzed that ummah degradation was begun at the line with the decrease of Islamic scientific tradition because of colonialization. Physical localization used a mentality, education, economic, and Devide et Empera strategies. But there was intellectual colonialization in scientific 'fashion' using liberalization and infiltration of the western worldview.

Some aspects of spreading the western worldview and hegemony can be viewed from these agendas: art, song, glamour life, and different lifestyle. In the other side, the religious practice was reduced as a cultural phenomenon in mere societies and contradicted with scientific traditions. The young generations which had no preparation in facing these problems would accept 'take for granted' this opinion.

We need to explore and examine matters relating to the attempt the Islamic revival which always begins with the rise of scientific traditions and education. The Trimurti, Founder of Gontor with his visionary and modern thoughts has answered this challenge since 90 years ago which is applied in this educational institution. So, this paper will discuss the reflection of the idea of Islamization which is focused on Adab and morality by looking at Gontor's curriculum design in the classroom and outside the classroom. 


\section{Islamization and Islamic Scientific Tradition}

The idea of Islamization has a variety of versions, there is a model of "Ayatisasi" that is by quoting verses from the Qur'an and Hadith, there is also a model of "IntegrationInterconnection", Even integration of science and religion in the "Pohon Ilmu" [1]. Besides, the ideas of several figures such as Kuntowijoyo with "Islamic Science", also in the international world, the method of Islamizing Contemporary Social Science by Al-Faruqi and Al-Attas.

Alfaruqi said that "Islamization is forming/reprinting knowledge to conform with Islam, by defining and reviewing the data used, rethinking, then reevaluating to reconcile existing things, and providing new goals and projections". Whereas Islamization according to Al-Attas there are two steps, namely isolating / removing foreign elements and key concepts from science, and then filling Islamic aspects into it [2].

The idea of Islamization of Science arises because of several things, especially the problems of the Ummah and its decline. According to al-Attas, the question arose from [3]

1. Confusion and error in knowledge

2. The loss of adab in the ummah.

Of the two conditions above led to the rise of leaders who did not fulfil legal leadership requirements in the Islamic ummah such as high moral, intellectual, and spiritual standards.

According to al-Attas, the root of all the problems above depend on each other and make a vicious circle. But the leading cause is chaos and errors in science. To cure this problem, we must first be able to overcome the issue of the loss of adab, because there will be no actual knowledge can be cultivated without the preconditions of adab in the person who seeks and receives it [3]. The loss of adab means the loss of the ability to distinguish the right and proper places from everything, which results in disguising everything at the same level, as well as the inability to recognize and understand the true leader in all areas of life.

Al-attas introduced the concept of education in Islam with ta'dib relating to adab. Because adab is the knowledge that prevents people from making mistakes in judgment, it is called adab because it brings the human condition to great things and keeps away from evil, this is preceded by educating and teaching people to control themselves and to attain good morals and customs. On this basis, the word adab is considered as the concept of education by al-Attas as explained above.

This time, we affirm that in Islam, manners and morals cannot be separated from the Islamic scientific tradition itself. It contains a vision of reality and truth in the Islamic worldview. And then it will be the foundation in life in any world, both academically and socially and others. IT seems to contrast with the concept of ethics in the West. Sometimes it is referred to as community consensus or mere cultural products. That is only personal and is only privacy. Moreover, at this time the dimensions of truth are quite confusing epistemologically especially - if we look at the relativity of moral and ethical values in this post-modern era.

\section{Reflection on Education and Teaching Curriculum in UNIDA Gontor}


Some of the things that built the Islamic worldview can be seen in full from the design of education and curriculum in Gontor and UNIDA. If we review the lessons at KMI which was Kulliyyatul Muallimin al-Islamiyyah, a high school system which usually integrated into pesantren, we will find all of them leading to Islamic, scientific and social values. Of course, it is framed by the conformity that is in sync with Aqidah, Sharia and Morals. Some of them can be seen in memorization lessons such as Mahfudzat, Hadith, and Interpretations from class 1 and others.

Some of which are related to knowledge, manners and morality include:

"Science without practice is like a fruitless tree"

"A person's kindness is better than his gold."

"Who has many good deeds, many brothers."

"The best of human beings is the best to be kind and the most beneficial to humans."

"Whoever goes out / goes to seek knowledge then he is fiy sabilillah (in the way of Allah) until he returns"

"If the man dies, his charity is cut off except for three cases, namely the shahqah jariyah, the knowledge used, and the pious child who prays for him"

"Your Lord has decreed that you worship none but Him and that you be kind to parents. Whether one or both of them attain old age during your lifetime, do not say a word of contempt to them, nor should you repel them, but address them in terms of honour"

"Such is the admonition given to him who believes in Allāh and the Last Day, and He (always) prepares a way out for those who fear Allāh. And He provides for him from (sources) he could never imagine. And if anyone puts his trust in Allāh, Allāh suffices him. For Allāh will surely accomplish His purpose: Truly, Allāh has appointed a due proportion for all things."

That is just a small part of the curriculum. It seems that we see that the content is an affirmation of the importance of morals and manners in the scientific tradition. Not just seeking knowledge, but also emphasizing its practice in daily activities.

The overall design of the curriculum will undoubtedly form a vision of becoming a Muslim, and a believer who is active in his faith runs the Shari'ah consistently and has a noble character. The course can be counted as an effort such as the Islamization of primary education. Until in Unida, finally, all of them were enhanced by the addition of a lecture curriculum in the form of a correct Islamic study methodology and debriefing of students to the challenges of 
contemporary thinking. All of this can be obtained from various discussions, lectures, and also the direction of the Chancellors, lecturers, and others.

If we also review the part of the outside-class curriculum at Gontor, we can see the design of disciplines, assignments, activities and others always oriented towards the values of the Pondok which are always delivered during the Week of Introductions. More than that, this matter was always quoted by the Leader in several events and meetings with various explanations and descriptions and extensive examples. It would be nice if we also review some of the things in the book "Pekan Perkenalan".

Life in Pesantren was inspired by the atmosphere that we can conclude in the Five Spirit (Panca Jiwa) as follows:

1. Sincerity: namely "sepi ing pamrih" (because it is not driven by the desire to obtain certain benefits), solely due to worship. It includes all the atmosphere of the Islamic boarding school's life. Kiyai is sincere in teaching; the students are sincere in learning, even to the employees in it. That is how there is a harmonious atmosphere of life between respected kyai and santri who are obedient and full of love and respect with all their sincerity. We understand this as infusing values that are sincerely charitable and devoted and provision to preach everywhere.

2. Simplicity: Simple does not mean passive (Javanese: narimo) and not poverty or poverty, isn't it! But it contains elements of strength and endurance, self-control in the face of the struggle for life with all difficulties. This simplicity emits a great soul, dares to go forward in struggling, and never retreats in all circumstances to finally grow strong mental / character which is a condition of success in life. Besides, even though this cottage is poor or productive as it is today, the values of the lodge in the waqf charter still cannot change. The value of simplicity is so evident on our campus, namely with the boarding school student system with a dormitory system, not luxurious but adjusting the conditions, tasks and facilities available.

3. Self-sufficient (Zelf-help) or self-reliance (standing on one's own feet): self-reliance not only in the sense that students always study and practice taking care of their interests, but also Islamic Boarding Schools themselves as Educational Institutions never rely on their lives to the help or mercy of others. That is 'Zelp berdruifing system' (both give contributions and are equally used). In that case, it is also not rigid so it refuses people who want to help the Pondok. Here we know that what students pay will return to the improvement of student facilities themselves, but this is also related to the maintenance and maintenance of these facilities, students are also given a share of responsibility.

4. Islamic Brotherhood: Life in Islamic Boarding Schools is filled with an atmosphere of intimate brotherhood so that all pleasures are felt along with the fabric of religious feelings. This Ukhuwwah (brotherhood), not only during the boarding school itself but also affects the unity of the ummah in the community after returning from the 
hut. It can be seen that with a dormitory system students can meet new friends even from various regions and backgrounds. Not to mention new friends who will get on college and other activities.

5. Free Soul: free in thinking and doing, free in determining the future and choosing the way of life in society. This freedom even freed from foreign and colonial influences. It's just that in this freedom we often encounter harmful elements, namely if they are misused, so that they are too free (liberal), so they lose direction and purpose or principle.

Some of the directions and goals of education in Pondok Modern are:

1. Community: All teaching and assignments that have been delivered by the pesantren, both in the form of lessons in class and outside the classroom, will all be encountered in the struggle for life in the community. Strictly speaking, not only is it too essential or remembering what must be learned at the University, but also remembering what will be found in the community. Namely, it is hoped that it is not awkward to become an elementary school teacher, Madrasah, whether teaching religion or general science. And it is not awkward to be an organization manager, priest, preacher, and others. It is undoubtedly related to the value of simplicity, namely Simple does not mean weak, and does not mean educating or teaching poor people, and vice versa. Pure is a matter of luck; it can facilitate an honest and clean life. Because life is luxurious and knows no limits easily affected by the devil's invitation to evil, and can cause forgetfulness to humanity, responsibility and gratitude.

2. No Party: Lessons and education in Pondok and University have absolutely no connection and relevance to the party or group. It is always ongoing, following the motto of Pondok Modern in educating, so that students are free-minded, the adherents of the ummah, above and for all groups. Furthermore, after leaving Gontor, they were free to return to their respective groups without reducing their principle as someone who is Muslim believer.

3. Main Objectives to Islamic Boarding Schools are Worship, Thalabu al-Ilm is not to be an employee: The cottage is not educating so that the Santri become employees, but to be active in thalabul ilmi with the holy intention of worship fulfilling religious orders. About later being able to become an employee or not, is not at all the basis of thought or calculation. It is even expected that the santri will be able to become people who lead a business or organization, or friends in entrepreneurship. In that, of course, it depends on the soul and character, personal and mental. We see that there are many activities and programs in UNIDA that support this direction. There are many facilities for students to 'Think About, Remembrance, and Body' as well as others. The other form is the existence of scientific activities such as weekly thought discussions, assignments to be boarders or different units. But of course, all of them return to their own beliefs, in ahsantum, ahsantum li anfusikum, wa in asa'tum falaha. 
Like it or not, humans are forced to be disciplined or disciplined. Whoever does not follow, will undoubtedly be affected either short term or long term. Animals in the forest are also exposed to discipline. Climate discipline, control of circumstances and place, and food. Therefore, people will not be $100 \%$ free from various disciplines. Islam contains critical lessons about discipline and self-discipline. Remember to pray with time, fasting, and others.

Then we must not misinterpret the words free or free. Free does not mean undisciplined, but free is the freedom of mind in choosing best disciplines that are obeyed. Running control is very light, especially if you have the intention and want. But it is tough if done with all coercion. It is as revealed in the Qur'an 2:45: Illa 'al al-Khasyi'in.

In terms of discipline and regulation, no written law in Gontor can be seen and read by residents and visitors. So how does the hut maintain order and security for all students who study in it? The answer is with dhamir (sound heart), conscience, small heart, or subtle feelings. So if the dhamir states it is not right, then the essence is that one's dhamir never misleads him. Only, that most people often deceive themselves, do things that are not following heart feelings. So, for this reason, it is necessary to increase the firmness of faith, because it can be implemented with sincerity and controlling lust.

In Gontor there is 'perpeloncoan' (introduction). It is interpreted as "enhancing the soul and feeling", namely returning to youth for the sake of education. Santri is also very demanding hazards/introductions. The goal is to be able to be filled, able to be formed, and ask to be corrected. Like a young man, if he will enter this Educational Institution, it means he is ready to be educated, ready to be trained, formed and corrected. And means also have to throw off pride, even though in the community and his village he has been praised and glorified.

Who corrects? The answer is from all angles. The caretaker, the teacher, the head of the room, the leader of Rayon, my compatriots, the management of OPPM, up to self-correction. It is because everything is in one congregation, and all are responsible for the good of their friends. Life in the pesantren is not differentiated between rich and poor, old and young; who is dangerous, that's the lucky one. If at UNIDA, there are also lecturers, campus staff and bureaus, even DEMA, and friends in the faculty and in rooms that will help correct ourselves. It is very necessary, remembering in the Qur'an 96:6: Inna al-Insaana la yathgha And the nature of feeling quite perhaps like qulubuna ghulfun.

Concerning this, we see that there are Opspek (Campus Orientation) activities, and various activities specifically for specific semesters, of course, this is the foundation. If you also look at multiple assignments and activities, such as TPA, the committee, the management of the organization or unit and the university bureau, all appointments for the new administration are based on this. Of course, all forms of hazing in Gontor and UNIDA are always based on values and 'Panca Jiwa Pondok', not free and careless so that they appear without educational value. 


\section{Conclusion}

The idea of Islamization is one of the efforts of Muslims in dialogue with other civilizations, while also maintaining the identity and essence of Islam itself. We have also seen in Islamic history, that the rise of the ummah can be started from the mastery and deepening of Islamic science itself. Besides, the process and the proliferation of scientific traditions supported by good manners and morals are equally essential keys.

Theoretically, many scholars and Islamic leaders have written many books about this idea and various alternatives and steps. His inspiration, of course, comes from Islamic history and especially the key concepts that are in the Qur'an and Hadith. It indicates that God always Maintain the truth of the Qur'an in various ways. Not just writing it, many scholars recorded throughout the ages established schools in the form of halaqoh or madrasa.

For comparison, these efforts have proceeded and proceeded at UNIDA Gontor. We can review the Gontor curriculum both inside and outside the classroom, as well as the curriculum at UNIDA specifically in the methodology of Islamic studies. That is, we already have a wellestablished system; it can even be an alternative to miniature or role model business Islamization. The curriculum is indeed the result of the founding ijtihad that has gone through a strict scientific ethos and practices of worship and muamalah to the level of ihsan.

\section{References}

[1] R. A. Lukens-Bull, Islamic higher education in Indonesia: Continuity and conflict. USA: Palgrave Macmillan, 2013.

[2] M. Y. Hussain, Islamization of Human Sciences. Kuala Lumpur: International Islamic University Malaysia, 2006.

[3] S. M. N. Al-Attas, The Concept of Education in Islam: A Framework for an Islamic Philosophy of Education. Bandung: Penerbit Mizan, 1984. 